DOI:

\title{
2014-2020 Yılları Arasında Muhasebe Ve Finansman Dergisi'nde Yayınlanan Makalelerin Bibliyometrik Profilinin İncelenmesi*
}

\author{
Funda KARAASLANOĞLU** \\ Elif Tuğba ŞAHİN***
}

\begin{abstract}
ÖZET
Bu çalışmada, 2014-2020 yılları arasında muhasebe ve finans alanının öncül dergilerinden Muhasebe ve Finansman Dergisi'nde yer alan makalelerin, çeşitli parametreler çerçevesinde bibliyometrik özelliklerinin belirlenmesi amaçlanmaktadır. Çalışmada, içerik analizi yöntemi ile 370 makale incelenerek mevcut durum ortaya konulmuştur. Araştırma bulgularına göre, en çok makalenin 2020 yılı, en az makalenin 2014 yılında yayınlandiğı; makalelerde nitel araştırma yöntemlerinin nicel araştırma yöntemlerine oranla daha fazla kullanıldiğı tespit edilmiştir. İçerik Analizi ve Örnek Olay Analizi, makalelerde en çok kullanılan analiz teknikleridir. Yayınlanan makalelerin sayfa sayılarının en az 12, en çok 32 olduğu, makalelerde yerli kaynaklardan daha fazla yabancı kaynaklardan yararlanıldı̆̆ tespit edilmiştir. Makalelerin en çok Uludağ Üniversitesi, Dokuz Eylül Üniversitesi ve Burdur Mehmet Akif Ersoy Üniversitesi'nde çallşan yazarlar tarafindan hazırlandığıl, yayınlanan 370 makale içinde en az 2014 yılında 136 ve en fazla 2020 yılında 250 anahtar kelime olmak üzere toplamda 1.393 anahtar kelime kullanıldı̆̆ belirlenmiştir. En fazla çalışmanın Doktor Öğretim Üyeleri tarafindan yazıldı̆̆ belirlenmiştir.
\end{abstract}

Anahtar Kelimeler: Muhasebe ve Finansman Dergisi, Bibliyometrik Özellikler, İçerik Analizi.

JEL Sinıflandırması: I21, I23, M41.

The Investigation of the Bibliometric Profile of the Articles Published in the Journal of Accounting and Finance between 2014-2020

\section{ABSTRACT}

In this study, it is aimed to determine the bibliometric properties of the articles published in the Journal of Accounting and Finance, one of the leading journals of the field of accounting and finance, between 2014-2020 within the framework of various parameters. In the study, 370 articles were examined by the content analysis method and the current situation was revealed. According to the research findings, the most articles were published in 2020 and the least in 2014; It was found that in these articles, qualitative research methods are used more than quantitative research methods. Content Analysis and Case Study Analysis are the most commonly used analysis techniques in articles. It was determined that the number of pages of the published articles was at least 12 and at most 32, and it was determined that foreign sources were used more than domestic sources in the articles. It was determined that the articles were mostly prepared by authors working at Uludag University, Dokuz Eylul University and Burdur Mehmet Akif Ersoy University, and a total of 1,393 keywords were used, with at least 136 keywords in 2014 and at most 250 keywords in 2020 out of 370 published articles. It was determined that the most studies were written by a Doctoral Faculty Member.

Keywords: Journal of Accounting and Finance, Bibliometric Features, Content Analysis.

Jel Classification: I21, I23, M41.

\footnotetext{
* Bu makale, 23-25 Nisan 2021 tarihleri arasında gerçekleştirilen VI. Uluslararası Muhasebe ve Finans Sempozyumunda bildiri olarak sunulmuştur.

Makale Gönderim Tarihi: 09.06.2021, Makale Kabul Tarihi: 26.06.2021, Makale Türü: Nitel Araştırma

** Öğr. Gör., Türk Hava Kurumu Üniversitesi, İşletme Fakültesi, fundaer@thk.edu.tr, ORCID: 0000-0003-00363699.

*** Arş. Gör., Türk Hava Kurumu Üniversitesi, İşletme Fakültesi, etsahin@thk.edu.tr, ORCID: 0000-0002-87270278
} 


\section{GİRiş}

Bilimsel çalışmaların çeşitli öğelerinin sayısal analizler ve istatistikler vasıtası ile incelenmesi ile ilgilenen bibliyometri konusuna yönelik ilk çalışmalar 1920 öncesinde gerçekleştirilmiş olmakla birlikte bibliyometri kavramı, Pritchard tarafindan (1969); "kitaplar ve iletişim ortamlarına istatistiksel ve matematiksel yöntemlerin uygulanması" olarak tanımlanmıştır (Forsman, 2008:15).

Türkiye'de, bibliyometri yöntemi ile yapılan ilk çalışmanın, Özinönü (1970)'nün astronomi, fizik, biyoloji, matematik, yer bilimleri ve kimya alanlarındaki bilimsel verimliliklerin ölçüldüğü "Growth in Turkish Positive Basic Sciences” çalışması olduğu kabul edilmektedir (Çetinkaya ve Çetin, 2016: 234).

Bibliyometri yöntemi, bilimsel yayınların nicel analizi ile bilimdeki değişimleri ve gelişimi görmek, farklı çalışmaların birbirleri ile bağlantılarını incelemek, herhangi bir kavram veya alan ile ilgili genel yönelimlerin belirlenmesi gibi farklı amaçlarla çeşitli disiplin alanlarında giderek yaygınlaşmaktadır (Gülmez vd., 2021: 5).

Bilimsel çalışmaların çeşitli parametrelerinin istatistiki olarak incelenmesiyle ilgilenmekte olan bibliyometri yönteminde sağlanan istatistiki sonuçlar 1şı̆̆ında, belirli bir alana ait genel yapı ortaya konulabilmektedir (Zan, 2012: 15).

Muhasebe ve Finansman Dergisi, 1998 yılının sonlarına doğru Türkiye'de yer alan üniversitelerdeki muhasebe ve finans alanında çalışan öğretim üyelerinin derneği olarak kurulmuştur. 1999-2011 arası fiziki olarak yayımlanmış, 2011 yılının Nisan sayısından itibaren ise elektronik olarak yayımlanmaya başlamıştır. Yılda 4 defa (3 ayda bir) çıkarılan Muhasebe ve Finansman Dergisi; TUBITAK-ULAKBIM (Sosyal Bilimler Veri Taban1), EBSCOhost (Business Source Complete), ASOS Index, Index Copernicus ve Şubat 2016 yılından itibaren ise ProQuest veri tabanları tarafından taranmaktadır (MUFAD, 2021).

$\mathrm{Bu}$ çalışmanın amacı, Muhasebe ve Finansman Dergisi'nde yer alan makaleleri bibliyometrik nitelikler açısından incelemektir. İlk bölümünde, muhasebe ve finans alanında gerçekleştirilmiş olan bibliyometrik çalışmalar ele alınmıştır. Bir sonraki bölümde çalışmanın metodolojisi ve bulgularına yer verilmiş, elde edilen sonuçlara ilişkin bilgiler ve öneriler sunulmuştur.

\section{LITERATÜR TARAMASI}

Ulusal ve uluslararası literatürde muhasebe ve finans bilimine yönelik faaliyet gösteren dergilerin bibliyometrik incelemelerini içeren çok sayıda çalışma yer almaktadır.

Hotamışlı ve Erem (2014) çalışmalarında, Muhasebe ve Finansman Dergisi'nde 2005 ile 2013 yılları arasındaki 562 adet makaleyi incelemişlerdir. İnceleme sonucunda, finansal performans, kamu ekonomisi ve finansal piyasalar konularına ağırlık verildiği, en fazla yayın yapan kurumların Marmara Üniversitesi, Trakya Üniversitesi ile İstanbul Üniversitesi olduğu ve toplamda 112 kurumun katkıda bulunduğu, en çok dergilere atıf yapıldığı ve genellikle bireysel çalışmalara yer verildiği belirlenmiştir. 
Apak vd. (2016) çalışmalarında, Muhasebe ve Finans Tarihi Araştırmaları Dergisi’nde 2011 -2016 yılları arasında yayınlanmış 107 makaleyi incelemişlerdir. İnceleme sonucuna göre, en fazla yayın yapan kurumların Marmara Üniversitesi ve Dokuz Eylül Üniversitesi olduğunu, en çok dergilere atıf yapıldığını, en çok makalenin 2013 ve 2015 yıllarında yayınlandığını ve makalelerin çoğunun kavramsal gerçekleştiğini belirlemişlerdir.

Akgün ve Karataş (2017) çalışmalarında, Muhasebe ve Denetime Bakış Dergisi'nde 2000 - 2016 yıllarında arasındaki 380 adet makaleyi incelemişlerdir. Araştırmada, ağırlıklı olarak maliyet ve yönetim muhasebesi ve denetim alanlarındaki konuların çalışıldığı, en çok katkı sağlayan kurumlar arasında Dokuz Eylül Üniversitesi, Ankara Üniversitesi ve Gazi Üniversitesi'nin olduğu, en çok yerli kaynak kullanılarak atıf yapıldığı, genelde bireysel çalışmalara yer verildiği ve dergiye en çok katkıyı doktor öğretim üyesi unvanlı yazarların yaptığ

Şen vd. (2017), 2009 - 2015 y1lları arasinda Muhasebe ve Finansman (MUFAD), Muhasebe Bilim Dünyası (MÖDAV), Muhasebe ve Vergi Uygulamaları (MUVU) ile Muhasebe ve Denetime Bakış (BAKIŞ) dergilerinde yayınlanmış olan 852 adet makaleyi bibliyometrik olarak incelemiş, inceleme sonucunda elen alınan yıllar arasında en fazla makalenin MÖDAV dergisinde yayınlandığı ve yapılan çalışmalarda önemli oranda makale ve bildirilerden yararlanıldığı tespit edilmiştir.

Merigo ve Yang (2017) tarafindan yayınlanan "Accounting Research: A Bibliometric Analysis" isimli çalışmada, Web of Science veritabanı kullanılarak muhasebe araştırmalarına bibliyometrik bir bakış açısı sunmak amaçlanmıştır. Çalışma bulgularına göre alandaki en etkili dergilerin The Journal of Accounting and Economics, Journal of Accounting Research, The Accounting Review and Accounting, Organisations and Society olduğu sonucuna ulaşılmıştır.

Özbek ve Badem (2018) çalışmalarında 2008-2017 yıllarında Muhasebe ve Vergi Uygulamaları Dergisi'nde yayımlanmış 149 makaleyi incelemişlerdir. İnceleme neticesinde, yayımlanan makalelerin çoğunlukla erkek yazarlara ait olduğunu, en fazla yayın yapan yazar unvanının yardımcı doçent doktor olduğunu, makalelerin çoğunlukla Gazi Üniversitesi'ne ait olduğunu, makalelerinin çoğunlukla tek yazarlı olduğunu, en çok "muhasebe" jel kodunun kullanıldığını ve en çok çalışılan konunun "muhasebe standartları" olduğunu belirlemişlerdir.

Temelli ve Karcıoğlu (2018) çalışmalarında 2010-2017 yıllarında Muhasebe ve Vergi Uygulamaları Dergisi'nde yayımlanmış 123 makaleyi incelemişlerdir. İncelemeleri neticesinde, çalışmalara atıf yapma durumları incelendiğinde çok az çalışmada dergiye atıf yapıldığı, en verimli yazarın 6 makaleye sahip olduğu, makalelerin çoğunluğunun akademisyenlere ait olduğu, makalelerin çoğunluğunun yardımcı doçent doktorlara ait olduğu, makalelerin çoğunlukla Gazi Üniversitesi ve Selçuk Üniversitesine ait olduğu, en fazla makalenin ve en fazla kaynakça kullanımının 2012 yılında yer aldığı ve çalışmaların çoğunlukla nitel şekilde gerçekleştirildiği belirlenmiştir.

Gündüz (2018) tarafından yapılan çalışmada 2014-2016 yılları arasında akademik dergilerde yayınlanan muhasebe alanındaki makaleler analiz edilmiştir. İnceleme sonucunda muhasebe alanında en fazla makalenin 2014 yılında Muhasebe ve Finansman Dergisi ile Mali Çözüm Dergisi’nde, 2015 - 2016 yıllarında ise Muhasebe Bilim Dünyası Dergisi’nde 
yayınlandığı belirlenmiş, makalelerin en çok muhasebe denetimi, muhasebe ve denetim standartları ve finansal muhasebe alanlarında hazırlandığı tespit edilmiştir.

Ardianto ve Anridho (2018), 2015 yılında 15. yayın hayatını tamamlamış olan Uluslararası Dijital Muhasebe Araştırmaları Dergisi (IJDAR)'nde 2001 - 2015 yılları arasında yayınlamış olan 93 adet makaleyi incelemiştir. Çalışmada, IJDAR'a katkıda bulunan yazarların/kurumların çoğunlukla ABD, Avustralya ve İspanya ülkelerinden olduğu tespit edilmiştir.

Chiu vd. (2019) tarafından muhasebe bilgi sistemlerinin yoğun olarak çalışıldığ dergi belirlenmiş, belirlenen dergilerde 2004 -2016 yılları arasında yayınlanmış olan toplam 681 adet makale bibliyometrik analize tabi tutulmuştur. Çalışmada, dergilerin tekil bir odak noktası olmadığı, makalelerin geniş bir perspektifte konuları ele aldığı ve makalelerin genel olarak gelişmekte olan teknolojilere yönelik çalışmalar olduğu sonucuna varılmıştır.

Kumar vd. (2020) 2019 yılında 20. yayın yılını kutlayan Uluslararası Muhasebe Bilişim Sistemleri Dergisi (IJAIS)'nin analizini yapmış ve hem dergi yayınlarında hem de atıf sayılarında artış olduğu sonucuna ulaşılmıştır. Ayrıca Amerika Birleşik Devletleri'ne bağlı yazarların en üretken yazarlar, Avustralya kurumlarının da en üretken kurumlar olarak dergiye katkıda bulundukları tespit edilmiştir.

Linnenluecke vd. (2020), son 60 y1lda Muhasebe ve Finans (Accounting \& Finance) Dergisi'ne yapılan katkıları sistematik olarak incelemiş, kurumsal sosyal sorumluluk ve sürdürülebilir finans gibi son zamanlarda gündemde olan konular dâhil olmak üzere zaman içinde ortaya çıkan önemli araştırma eğilimlerini sunmuşlardır.

\section{METODOLOJI}

Bu çalışmanın amacı, Türkiye'nin muhasebe ve finans alanında öncül dergilerinden biri olan Muhasebe ve Finansman Dergisi'nde yayınlanan makalelerin çeşitli bibliyometrik özellikler açısından analiz edilerek, bu alanda var olan çalışmalar hakkında bilgiler elde edebilmek ve bu alanda çalışanlara yardımcı olabilmektedir.

Araştırmanın kısıtları aşağıda belirtilmiştir:

- $\quad$ Araştırma, yalnızca Muhasebe ve Finansman Dergisi ile sınırlı tutulmuş, diğer akademik dergilerde alan ile ilgili yayınlanan makaleler kapsam dışı bırakılmıştır.

- Diğer kısıt ise, araştırmaya konu olan yıl aralığının 2014 - 2020 ile sınırlandırılmasıdır. Muhasebe ve Finansman Dergisi 1999 yılında yayın hayatına başlamış olduğundan, araştırmanın öncelikle 1999 yılı ile 2020 yılı arasını kapsayacak şekilde yapılmasının uygun olacağı düşünülmüştür. Ancak, derginin 1999-2004 yılları arası basılı ve/veya elektronik eski sayılarına ulaşılamamıştır. Bu nedenle araştırmaya 2005 yılı itibariyle başlamak düşünülse de, Hotamışlı ve Erem tarafından, Muhasebe ve Finansman Dergisi'nde 2005-2013 yılları arasında yayınlanmış olan makalelerin bibliyometrik analize tabi tutulduğu tespit edilmiştir. Araştırmanın kapsamını oluşturan zaman aralığı, hem anılan yıllara ilişkin mükerrer çalışma yapmamak hem de sürekliliği sağlamak amacıyla 2014-2020 yılları arası olarak belirlenmiştir. 
Çalışmanın amacı doğrultusunda Muhasebe ve Finansman Dergisi'nde 2014-2020 yıllarında yayınlanan makalelerin analizine yönelik belirlenen araştırma soruları:

1. Makalelerin yayın yılına göre dağılımı nasıldır?

2. Makalelerin yazar sayısına göre dağılımı nasıldır?

3. Makalelerin ait olduğu üniversite ve kurumlar hangileridir?

4. Anahtar kelimelere bağlantılı olarak en çok çalışılan konular nelerdir?

5. Yazarların unvanları nelerdir?

6. Makalelerin çalışma yöntemleri nelerdir?

7. Makalelerde kullanılan analiz teknikleri nelerdir?

8. Makalelerde yararlanılan kaynakların yerli/yabancı dağılımı nasıldır?

9. Makalelerin sayfa sayıları ne kadardır?

Çalışmada nitel araştırma yöntemlerinden bibliyometri tekniği kullanılmıştır. Veriler nitel araştırma yöntemlerinden doküman inceleme ile toplanmış ve elde edilen veriler içerik analizi ile analiz edilmiştir. Çalışmada kullanılan inceleme kriterleri; yayım yılı, yazar sayısı, hazırlanmış olduğu üniversite adı, hazırlanmış olduğu kurum adı, çalışmayı yürüten yazar adı ve unvanı, konu başlıkları, anahtar kelimeler, araştırma tasarımı (nitel/nicel), kullanılan veri analiz teknikleri, kaynakçadaki yerli/yabancı kaynak ağırlığı ve sayfa sayısıdır.

\section{BULGULAR}

\subsection{Yayın Yılına Göre Dağılım}

Ocak, Nisan, Temmuz ve Ekim ayları olmak üzere yılda 4 defa yayınlanan Muhasebe ve Finans Dergisinde yıllar itibariyle yayınlanmış olan makale sayıları Grafik 1'de verilmiştir:

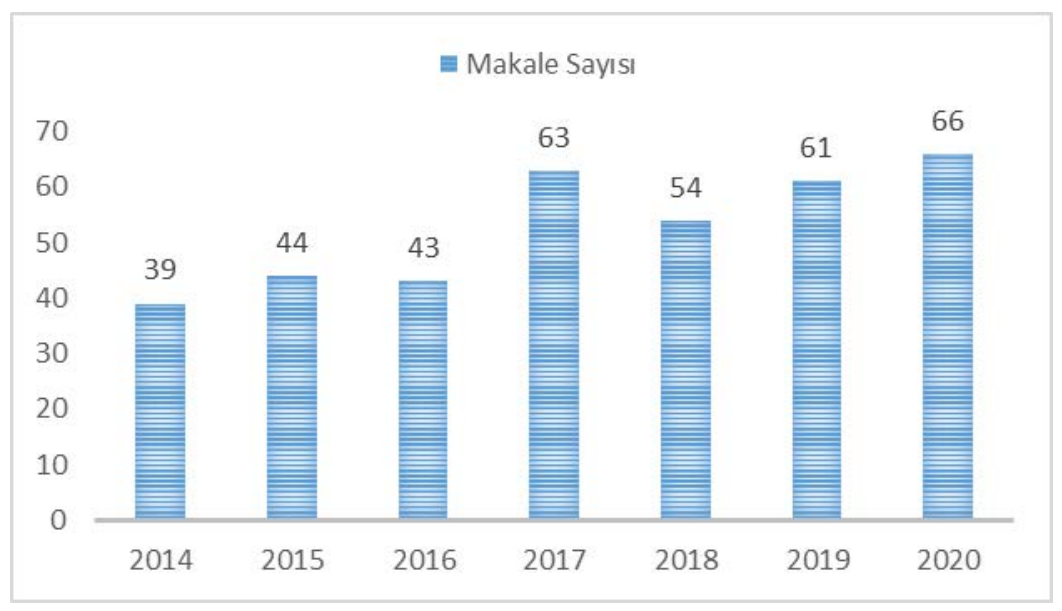

Grafik 1. Yıllar İtibariyle Yayınlanmış Makale Sayıları

Grafik 1'e göre en çok makale 2020 yılında, en az makale 2014 yılında yayınlanmıştır. Dergide her yıl 4 sayı yayınlanmasına rağmen, 2017 yılı Temmuz ayında "Özel Sayl" yayınlanmış olduğundan, 2017 yılına özgü olarak 5 sayı yayınlanmıştır. 


\subsection{Makalelerin Yazar Sayısına Göre Dağılımı}

Çalışma kapsamında ele alınan 370 makalenin toplam 566 yazar tarafından yazıldığı belirlenmiştir. Makale başına düşen ortalama yazar sayısı 1,53'tür. Yazar dağılımında tek yazarlı makale çalışması 134, iki yazarlı makale çalışması 168, üç yazarlı makale çalışması 56 ve dört yazarlı makale çalışması 12 olarak tespit edilmiştir.

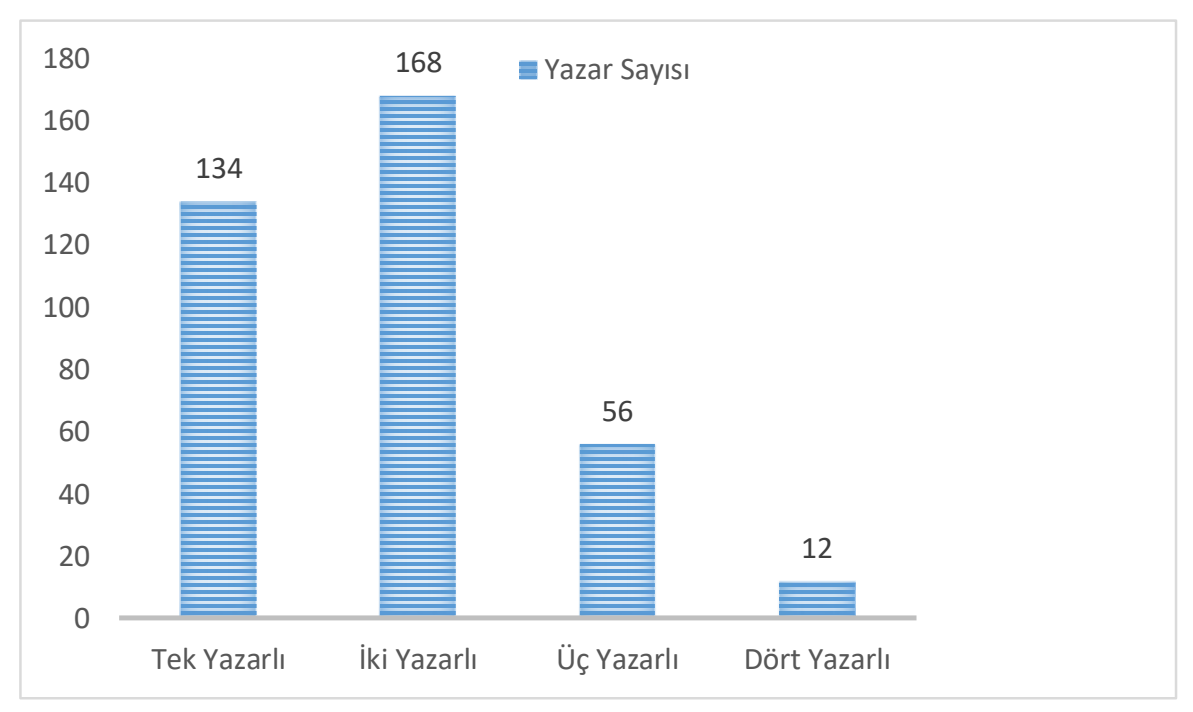

Grafik 2. Makalelerdeki Yazar Sayıları

\subsection{Yazar/Yazarların Üniversite / Kurum Dağılımı}

Muhasebe ve Finansman Dergisi'nde 2014-2020 y1lları arasında yayınlanan 370 makalenin yazarları ve yazarların bağlı olduğu üniversite/kurum incelemesi yapıldığında en fazla çalışma yapılan üniversite/kurumun 21 makale çalışması ile Uludağ Üniversitesi olduğu tespit edilmiştir. Uludağ Üniversitesi'ni 16 makale çalışması ile Dokuz Eylül Üniversitesi, 13'er makale çalışması ile Burdur Mehmet Akif Ersoy Üniversitesi, Süleyman Demirel Üniversitesi ve Pamukkale Üniversitesi, 12 makale çalışması ile Atatürk Üniversitesi'nin en çok katkı yapan üniversite/kurum olduğu belirlenmiştir.

Tablo 1. Üniversitelerin Dağılımı

\begin{tabular}{|l|c|l|c|}
\hline Uludağ Üniversitesi & 21 & Uşak Üniversitesi & 6 \\
\hline Dokuz Eylül Üniversitesi & 16 & Yalova Üniversitesi & 6 \\
\hline Burdur Mehmet Akif Ersoy Üniversitesi & 13 & Hitit Üniversitesi & 6 \\
\hline Pamukkale Üniversitesi & 13 & Bilecik Şeyh Edebali Üniversitesi & 5 \\
\hline Süleyman Demirel Üniversitesi & 13 & Bülent Ecevit Üniversitesi & 5 \\
\hline Atatürk Üniversitesi & 12 & Kahramanmaraş Sütçü İmam Üniversitesi & 5 \\
\hline Sakarya Üniversitesi & 10 & Hacı Bektaş Veli Üniversitesi & 5 \\
\hline Mersin Üniversitesi & 8 & Gaziosmanpaşa Üniversitesi & 5 \\
\hline Celal Bayar Üniversitesi & 8 & Trakya Üniversitesi & 5 \\
\hline Çankırı Karatekin Üniversitesi & 8 & Cumhuriyet Üniversitesi & 5 \\
\hline Çanakkale Onsekiz Mart Üniversitesi & 8 & Afyon Kocatepe Üniversitesi & 4 \\
\hline Erciyes Üniversitesi & 8 & Akdeniz Üniversitesi & 4 \\
\hline
\end{tabular}




\begin{tabular}{|l|c|l|c|} 
Adnan Menderes Üniversitesi & 7 & Gazi Üniversitesi & 4 \\
\hline Anadolu Üniversitesi & 7 & Ondokuz Mayı Üniversitesi & 4 \\
\hline Muğla Sıtkı Koçman Üniversitesi & 7 & İstanbul Üniversitesi & 4 \\
\hline Kırıkkale Üniversitesi & 7 & Başkent Üniversitesi & 4 \\
\hline Gaziantep Üniversitesi & 7 & Hacettepe Üniversitesi & 4 \\
\hline Düzce Üniversitesi & 7 & Osmaniye Korkut Ata Üniversitesi & 4 \\
\hline Yıldırım Beyazı Üniversitesi & 7 & Erzincan Üniversitesi & 4 \\
\hline Çukurova Üniversitesi & 7 & Selçuk Üniversitesi & 4 \\
\hline Dumlupınar Üniversitesi & 7 & Kars Kafkas Üniversitesi & 4 \\
\hline Balıkesir Üniversitesi & 6 & Bozok Üniversitesi & 4 \\
\hline Karabük Üniversitesi & 6 & & \\
\hline
\end{tabular}

\subsection{Yazarların Akademik Unvan Dağılımı}

Muhasebe ve Finansman Dergisi'nde makalesi yayınlanan yazarların akademik unvan dağılımına baktığımızda; en fazla Doktor Öğretim Üyesi ${ }^{1}$ (194) unvanına sahip yazarların çalışmalarının yer aldığı belirlenmiştir. Doktor Öğretim Üyesi unvanına sahip yazarların ardından en çok katkıda bulunan yazar unvanları ise sırasıyla; Doç. Dr. (140) ve Prof. Dr. (85) unvanlarıdır. Yıllık bazda bakıldığında ise; 2014 yılında Yrd. Doç. Dr. unvanına sahip yazarların 28, 2015 yılında Yrd. Doç. Dr. unvanına sahip yazarların 29, 2016 yılında Yrd. Doç. Dr. unvanına sahip yazarların 24, 2017 yılında Doç. Dr. unvanına sahip yazarların 29, 2018 yılında Dr. Öğretim Üyesi unvanına sahip yazarların 28, 2019 yılında Doç. Dr. unvanına sahip yazarların 22 ve 2020 yılında Dr. Öğretim Üyesi unvanına sahip yazarların 33 çalışmaya imza attıkları görülmüştür.

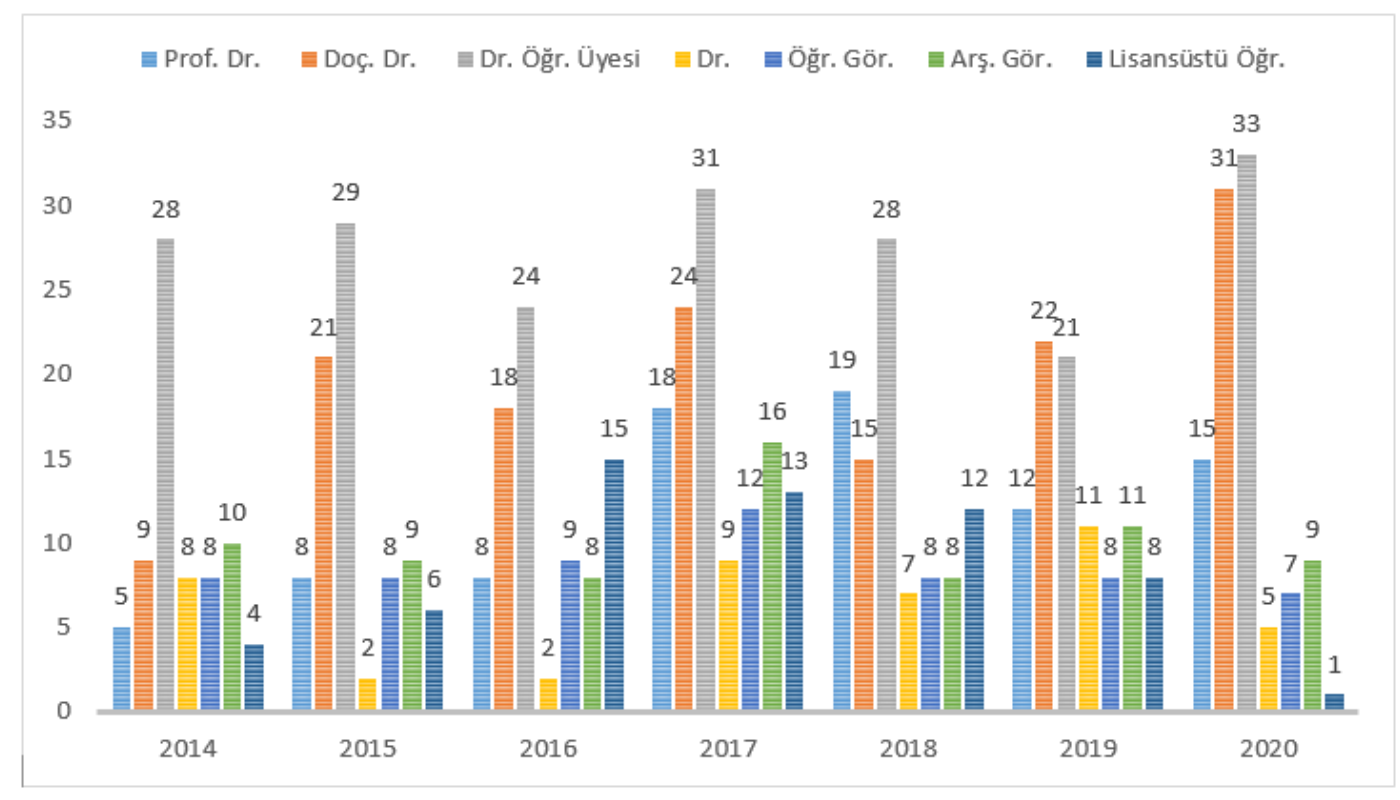

Grafik 3. Makalelerdeki Yazar Unvanları

1 22.02.2018 tarih ve 7100 sayılı "Yükseköğretim Kanunun ile Bazı Kanun ve Kanun Hükmünde Kararnamelerde Değişiklik Yapılması Hakkında Kanun" ile "Yardımcı Doçent" kadro unvanları "Doktor Öğretim Üyesi" olarak değiştirilmiştir. Bu değişiklik çerçevesinde Grafik 3'te "Yardımcı Doçent" kadrosu "Doktor Öğretim Üyesi” olarak alınmıştır. 


\subsection{Makalelerin Konu Başlıklarına Göre Dağılımı}

Muhasebe ve Finansman Dergisi'nde yazılmış olan makalelerin konu başlıklarına göre ayrımını yapabilmek amacıyla, makalelere anahtar kelimeleri ile bağlantılı olarak bakılmıştır. Anahtar kelimelere bağlı kalmanın sebebi; bir makale birden fazla konuyu içinde barındırabilmektedir. Örneğin, bir makale muhasebe eğitimi konusu ile ilgiliyken, aynı zamanda muhasebe meslek mensuplarının muhasebe eğitimine ilişkin tutumlarını içerebilir.

Yayınlanan makalelerin konularını belirleyebilmek için anahtar kelimelerine bağlantılı olarak bakıldığında en fazla finansal performans ve TMS/TFRS konularında makale yazıldığı görülmektedir. Bu verilere ulaşabilmek için 2014-2020 yılları arasında yayınlanmış toplam 340 makalede kullanılan 1.393 anahtar kelimeye bakılmıştır.

Tablo 2. Makalelerin Konu Dağılımları

\begin{tabular}{|l|c|l|c|}
\hline Finansal Performans & 29 & Endeks & 7 \\
\hline TMS/TFRS & 24 & Sürdürülebilirlik & 7 \\
\hline Denetim & 21 & Çevre Muhasebesi & 6 \\
\hline Finansal Analiz ve Raporlama & 21 & Ekonomik Büyüme & 6 \\
\hline Muhasebe Eğitimi & 20 & Çalıșma Sermayesi & 5 \\
\hline Finansal Piyasalar & 17 & Etkinlik & 5 \\
\hline Muhasebe Uygulamaları & 12 & Türev Piyasalar & 5 \\
\hline Muhasebe Meslek Mensubu & 11 & Muhasebe Bilgi Sistemleri & 5 \\
\hline Karlılı/Temettü & 11 & Dijital Varlıklar & 5 \\
\hline Muhasebe Mesleği & 10 & Muhasebe Finans Yazını & 5 \\
\hline Davranıssal Finans & 10 & Hile Denetimi & 4 \\
\hline Volatilite & 10 & Yönetim Muhasebesi & 4 \\
\hline Finansal Okuryazarlık & 9 & Yatırım Kararı & 4 \\
\hline Finansal Bașarısızlık & 9 & Firma Değeri & 3 \\
\hline Risk Yönetimi & 9 & Maliyet Muhasebesi & 3 \\
\hline Maliyettleme Yöntemleri & 7 & Diğer & 28 \\
\hline Sermaye Yapısı & 7 & & \\
\hline
\end{tabular}

\subsection{Makalelerin Araştırma Yöntemlerine Göre Dağılımı}

Ele alınan yıllar bazında yayınlanan makalelere bakıldığında yapılan çalışmaların araştırma yöntemleri Grafik 2 'de belirtilmiştir: 


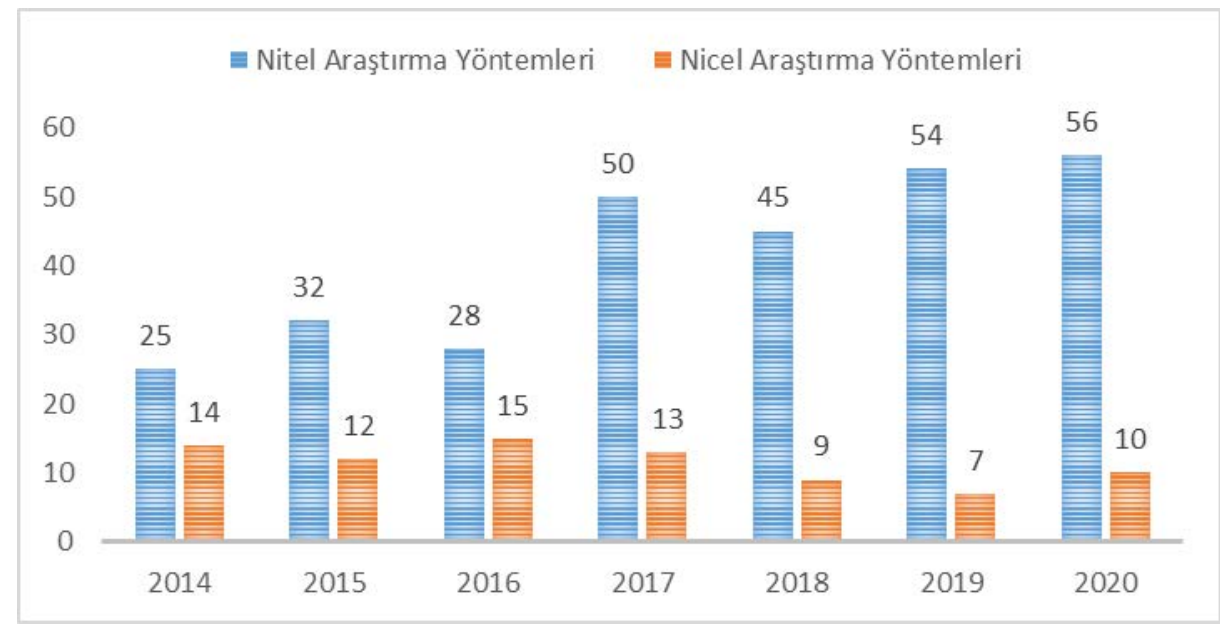

Grafik 4. Makalelerin Araştırma Yöntemlerine Göre Dağılımı

\subsection{Makalelerin Analiz Türüne Göre Dağılımı}

İlgili yıllar arasında yayınlanmış olan makalelerin analiz türüne bakıldığında; yayınlanmış olan makalelerde içerik analizi (62), örnek olay analizi (59) ve panel veri analizi (45), en çok tercih edilen analiz türü olarak belirlenmiştir.

Tablo 3. Analiz Türü Dağılımları

\begin{tabular}{|l|c|l|c|}
\hline İçerik Analizi & 62 & Faktör Analizi & 7 \\
\hline Örnek Olay Analizi & 59 & Nedensellik Analizi & 6 \\
\hline Panel Veri Analizi & 45 & Finansal Oran Analizi & 6 \\
\hline Regresyon Analizi & 41 & Karşıslaştırmalı Analiz & 6 \\
\hline İstatistiki Analizler & 35 & Veri Zarflama Analizi & 5 \\
\hline Frekans Analizi & 11 & Gri İlişkisel Analiz & 5 \\
\hline Korelasyon Analizi & 9 & Yapısal Eşitlik Modeli & 3 \\
\hline ANOVA & 9 & Portföy Analizi & 1 \\
\hline
\end{tabular}

\subsection{Makalelerin Kaynak Dağılımı}

2014-2020 yılları arası yayınlanan 340 makalenin yerli/yabancı kaynak dağılımına bakıldığında; makalelerde yerli kaynaklara oranla yabancı kaynaklardan daha fazla yararlanıldığı tespit edilmiştir. Yıllar itibariyle makalelerde kullanılan toplam yerli/yabancı kaynak sayıs1; 2014 yılında 483 yerli / 611 yabanc1, 2015 yılında 484 yerli / 684 yabanc1, 2016 y1lında 509 yerli / 763 yabanc1, 2017 y1lında 655 yerli / 1.175 yabanc1, 2018 y1lında 668 yerli / 957 yabanc1, 2019 yılında 939 yerli / 994 yabanc1 ve 2020 yılında 870 yerli / 1.550 yabancı kaynaktan yararlanılmıştır. Makale başına 12,2 yerli ve 18,2 yabancı kaynak düşmektedir. 


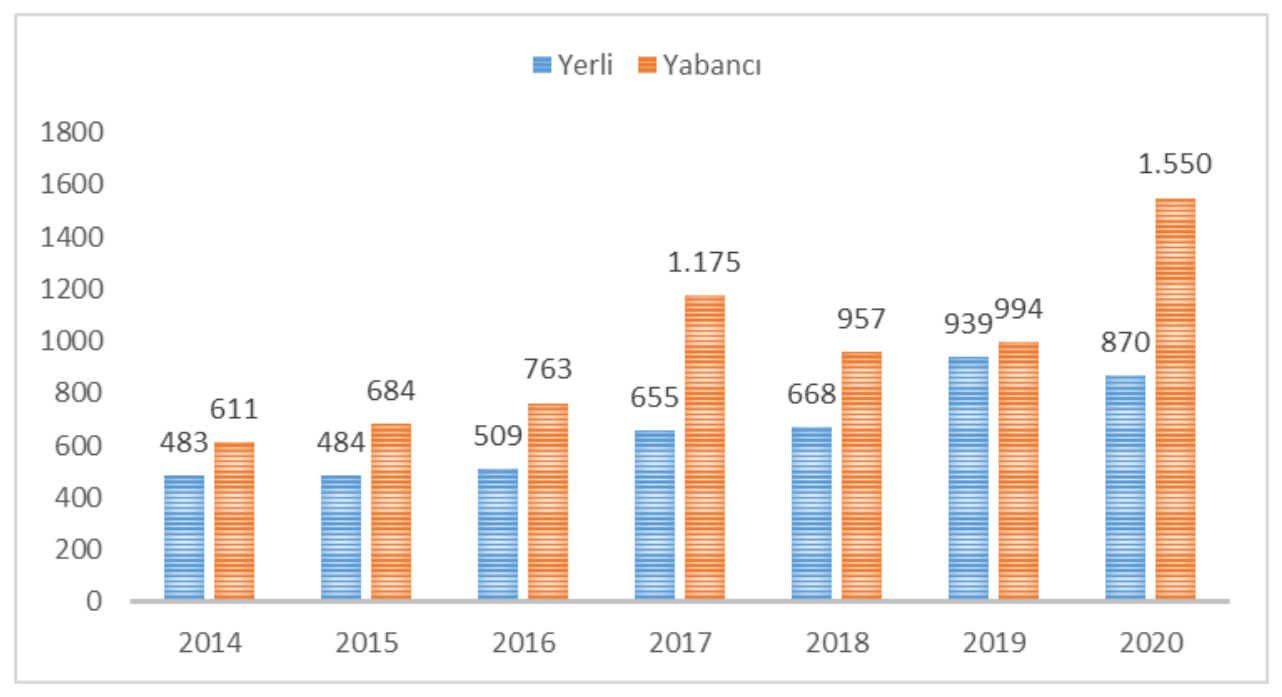

Grafik 5. Makalelerin Kaynak Türü Dağılımı

\subsection{Makalelerin Sayfa Sayısı Dağılımı}

Dergide yayınlanan 340 makalenin sayfa sayıları dağılımı yıl bazında incelenmiş ve her yıl yayınlanan dört sayıdaki toplam sayfa sayıları; 2014 yılında 732 sayfa, 2015 y1lında 802 sayfa, 2016 yılında 823 sayfa, 2017 yılında (2017 yılında "Özel Sayı" yayınlandı̆̆ından dolayı beş sayı) 1.198 sayfa, 2018 yılında 972 sayfa, 2019 yılında 1.154 sayfa ve 2020 y1lında 1.264 sayfa olup toplam sayfa sayıs $6.945^{\prime}$ tir. Yıllar itibariyle en az ve en fazla yayınlanan makale sayfa sayısı verileri Grafik 3'te verilmiştir:

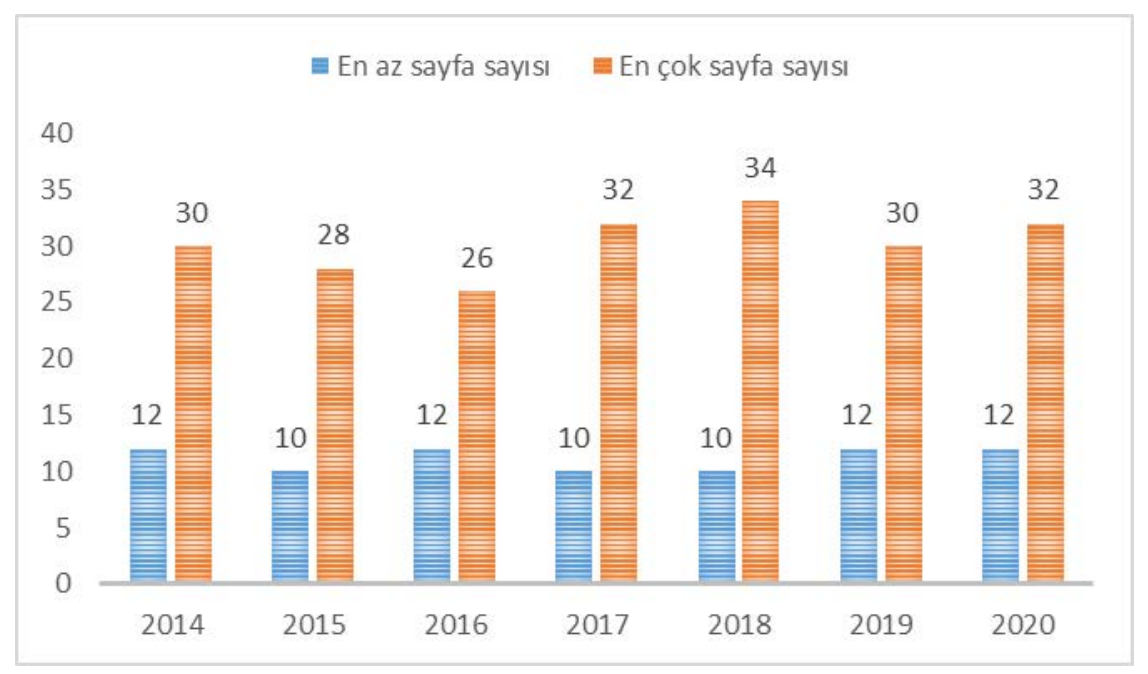

Grafik 6. Makalelerin Sayfa Sayısına Göre Dağılımı

\section{SONUÇ}

$\mathrm{Bu}$ çalışmada, 1999 tarihinde yayın hayatına başlayan, alanının öncül dergilerinden olan Muhasebe ve Finansman Dergisi'nde 2014-2020 yılları arasında yayınlanan makaleler, bibliyometrik analiz tekniği kullanılarak araştırılmıştır. 
Araştırma sonucunda, ele alınan yıllar arasında toplam 370 makalenin yayınlandığı, en fazla makalenin 66 çalışma ile 2020 yılında yayınlandığı, anılan toplam 370 makalenin 566 yazar tarafından yazıldığı belirlenmiştir.

Yayınlanan makalelerin yazar sayısı dağılımında, tek yazarlı makale çalışması 134, iki yazarlı makale çalışması 168, üç yazarlı makale çalışması 56 ve dört yazarlı makale çalışması 12 olarak tespit edilmiştir.

2014-2020 döneminde en çok makalenin 21 makale çalışması ile Uludağ Üniversitesi, 16 makale çalışması ile Dokuz Eylül Üniversitesi, 13'er makale çalışması ile Burdur Mehmet Akif Ersoy Üniversitesi, Süleyman Demirel Üniversitesi ve Pamukkale Üniversitesi’ne ait olduğu tespit edilmiştir.

Araştırma kapsamında ele alınan dönem içinde yayınlanan makalelerin, en fazla Doktor Öğretim Üyesi unvanına sahip yazarlar tarafından yayınlandıkları belirlenmiştir.

Yayınlanan makalelerin konularını belirleyebilmek için anahtar kelimelerine bağlantılı olarak inceleme yapılmış, en fazla finansal performans ve TMS/TFRS konularında makale yazıldığ 1 tespit edilmiştir.

Nitel araştırma yöntemlerinin nicel araştırma yöntemlerine nazaran 2014-2020 yılları arasındaki her yıl baskın oranda kullanıldığı tespit edilmiştir.

Ele alınan yıllar arasında yayınlanan makalelerde içerik analizi, örnek olay analizi ve panel veri analizi, en çok tercih edilen analiz türü olarak belirlenmiştir.

Son olarak, makalelerde yerli kaynaklara oranla, yabancı kaynakların daha fazla kullanıldığı, makalelerin sayfa sayısı incelemesinde ise, en az 10, en fazla 34 sayfalık makale çalışmasının yayınlandığı söylenebilmektedir.

Yapılan bu bibliyometrik araştırma sonucunda, muhasebe ve finans alanında yapılan araştırmalarda odaklanılan konu başlıklarının, araştırma yöntemleri ve analiz türü ağırlıklarının, yerli / yabancı kaynak dağılımının tespiti ile ilgili literatüre katkı sağladığı düşünülmektedir. Çalışmanın, bu alanda araştırma yapmayı düşünen araştırmacılara yol gösterici nitelikte olumlu bir etki oluşturabileceği beklenmekte ve konu, araştırma yöntemleri, analiz türü vb. başlıklarda ortaya çıkan bulguların araştırmacılara gelecek çalışmalar için 1şık tutacağı öngörülmektedir. Sonuç olarak, muhasebe ve finans ile ilgili yayınlanan makale çalışmaları, muhasebe ve finans alanında değişimlere ve yeniliklere yol açacaktır. Gelecek araştırmalarda yurtdışında ilgili alanda yayınlanan dergilerdeki makaleler, bibliyometri tekniği ile analize tabi tutularak karşılaştırmalı analiz gerçekleştirilebileceği düşünülmektedir. $\mathrm{Bu}$ analiz aracılığı ile ulusal ve uluslararası düzeyde muhasebe ve finans çalışmalarına hakim olunabilecektir.

\section{KAYNAKLAR}

Akgün, Melek - Karataş, Bekir (2017), "Muhasebe ve Denetime Bakış Dergisinde Yayımlanan Makalelerin Bibliyometrik Analizi (2000-2016)”, Muhasebe ve Denetime Bakış/Accounting \& Auditing Review, 17(52), ss.19-34. 
Apak, Sudi - Erol, Mikail - Öztürk, Seçil (2016), "Muhasebe ve Finans Tarihi Araştırmaları Dergisinde Yayınlanan Makalelerin Bibliyometrik Analizi”, Muhasebe ve Finans Tarihi Araştırmaları Dergisi, (11), ss.111-124.

Ardianto Ardianto - Anridho, Nadia. (2018), “Bibliometric Analysis Of Digital Accounting Research”, The International Journal of Digital Accounting Research, 18(1), pp.141159.

Chiu, Victoria - Liu, Qi - Muehlmann, Brigitte - Baldwin, Amelia Annette. (2019). “A Bibliometric Analysis Of Accounting Information Systems Journals And Their Emerging Technologies Contributions”, International Journal of Accounting Information Systems, pp.24-43.

Çetin, Ali - Çetinkaya Bozkurt, Özlem (2016), “Girişimcilik ve Kalkınma Dergisi’nin Bibliyometrik Analizi”, Girişimcilik ve Kalkınma Dergisi, 11 (2), ss.229-263.

Forsman, Maria (2008), “Do We Need a Qualitative Approach in Bibliometric Studies?”, (Zan, Burcu Umut, "Türkiye'de Bilim Dallarında Karşıllaştırmalı Bibliyometrik Analiz Çalışması”, Doktora Tezi, Ankara Üniversitesi Sosyal Bilimler Enstitüsü, 2012, ss.15).

Gülmez, Deniz - Özteke, İrem - Gümüş, Sedat (2020), “Uluslararası Dergilerde Yayımlanan Türkiye Kaynaklı Eğitim Araştırmalarının Genel Görünümü: Bibliyometrik Analiz”, Eğitim ve Bilim Dergisi, ss.1-27.

Gündüz, M. (2018), “Türkiye’de 2014-2016 Y1lları Arasında Akademik Dergilerde Muhasebe Alanında Yayınlanan Makalelerin Bibliyometrik Analizi”, Muhasebe Bilim Dünyası Dergisi, 20 (1), ss.236-257.

Hotamışlı, Mustafa - Erem, Işıl (2014), "Muhasebe ve Finansman Dergisi'nde Yayınlanan Makalelerin Bibliyometrik Analizi”, Muhasebe ve Finansman Dergisi, (63), ss.1-20.

Kıymetli Şen, İlker - Hatunoğlu, Zeynep - Terzi, Serkan (2017), "Muhasebe Araştırmalarında Muhasebe Eğitiminin Yeri ve Önemi: Muhasebe Dergileri Üzerine Bibliyometrik Bir Araştırma", Muhasebe ve Bilim Dünyası Dergisi, 19(1), ss.247-291.

Kumar, Satish - Marrone, Mauricio - Liu, Qi - Pandey, Nitesh (2020), Twenty Years of The International Journal of Accounting Information Systems: A Bibliometric Analysis. International Journal of Accounting Information Systems, 39, 100488, pp.1-19.

Linnenluecke, Martina K. - Marrone, Mauricio - Singh, Abhay K. (2020), Sixty Years of Accounting \& Finance: A Bibliometric Analysis of Major Research Themes And Contributions, Accounting \& Finance, 60(4), pp.3217-3251.

Merigó, Jose‘ M. - Yang, Jian-Bo (2017), “Accounting Research: A Bibliometric Analysis”, Australian Accounting Review, 27(1), pp.71-100.

Özbek, Cevdet Yiğit - Badem, Ahmet Cemkut (2018), "Muhasebe ve Vergi Uygulamaları Dergisi’nde Yayımlanmış Makalelerin Bibliyometrik Analizi (2008-2017)”, Muhasebe 
ve Vergi Uygulamaları Dergisi /Journal of Accounting \& Taxation Studies, 11(2), ss.216-247.

Temelli, Fatma - Karcıoğlu, Reşat (2018), "Muhasebe ve Vergi Uygulamaları Dergisinde Yayınlanan Makalelerin Bibliyometrik Analizi: 2010-2017 Dönemi”, Muhasebe ve Vergi Uygulamaları Dergisi /Journal of Accounting \& Taxation Studies, 11(2), ss.248268.

https://dergipark.org.tr/tr/pub/mufad/aim-and-scope (Erişim Tarihi:15.04.2021) 
